University of Nebraska - Lincoln

DigitalCommons@University of Nebraska - Lincoln

West Central Research and Extension Center, North Platte

Agricultural Research Division of IANR

$12-2008$

\title{
Release of Roadside Native Perennial Grasses following Removal of Yellow Starthistle
}

\author{
Stephen L. Young \\ University of Nebraska - Lincoln, steve.young@usu.edu \\ Victor P. Claassen \\ University of California - Davis
}

Follow this and additional works at: https://digitalcommons.unl.edu/westcentresext

Part of the Agriculture Commons

Young, Stephen L. and Claassen, Victor P., "Release of Roadside Native Perennial Grasses following Removal of Yellow Starthistle" (2008). West Central Research and Extension Center, North Platte. 15. https://digitalcommons.unl.edu/westcentresext/15

This Article is brought to you for free and open access by the Agricultural Research Division of IANR at DigitalCommons@University of Nebraska - Lincoln. It has been accepted for inclusion in West Central Research and Extension Center, North Platte by an authorized administrator of DigitalCommons@University of Nebraska - Lincoln. 


\title{
Release of Roadside Native Perennial Grasses following Removal of Yellow Starthistle
}

\author{
Stephen L. Young and Victor P. Claassen
}

\begin{abstract}
The ecological benefits of a roadside native perennial grass stand are :ompromised when invasive species become estab. lished. We evaluated the potential to regenerate existing native perennial grass stands populated with yellow starthistle (Centourea soistitialis) on a roadside planting in the lowland hilis of the interior Coast Range of northern California. The experiment was designed to determine the effects of mowing, burning, or herbicide spraying, atone and in combination, on the vegetative cover and density of native perennial grasses and $C$. solstitialis. The study site contained blue wildrye (Elymus glaucus) and purple needlegrass (Nassella pulchra) as well as $C$. solstitialis. Burn, herbicide, and mow treatments were applied in spring 2004. After one year, $C$. solstitialis cover was less than $2 \%$ in all treatments that included spraying and in two years, $C$. solstitialis was $2 \%$ or less in all treatments except burned plots $(8 \%)$ and control plots (16\%). By the end of two years, percent cover and activity (i.e., growth and dormancy) of native perennial grasses were significantly greater for management treatments that included at least two of the tested vegetation control techniques. This study suggests that a combination of vegetation control techniques is necessary to nearly eliminate $C$. solstitialis and increase late summer cover and activity of native perennial grasses.
\end{abstract}

Keywords: blue wildrye (Elymus glaucus), dormancy, integrated roadside ve getation management, purple needlegrass (Nassella pulchra), yellow starthistle (Centaurea so/stitialis).

The spread of invasive species is thought to be expedited by roadways and railways (Gelbard and Belnap 2003, Gelbard and Harrison 2003). Hansen and Clevenger (2005) found rransportarion corridors had a significanr effect on the spread and establishment of invasive non-native species. At 16-year-old revegetation sites along roads and pipelines near the Homestake-McLaughlin gold mine in northern California, for example, Williamson and Harrison (2002) measured increased proliferations of the non-native annual grasses compact brome (Bromus madritensis ssp. madritensis), soft brome (Bromus hordeaceus), and annual ryegrass (Lolium multiflorum).

Weed control costs for noxious weeds in the United States are

Ecological Restoration Vol. 26, No. 4, 2008 ISSN 1522-4740 E-ISSN I 543-4079 2008 by the Board of Regents of the University of Wisconsin System. estimated at about $\$ 5$ billion per year (Babbitr 1998). The curreat rate of spread for downy brome (Bromus tectorum), musk thistle (Carduus nutans), yellow starthistle (Centaurea solstitialis), Canada thistle (Cirsium arvense), perennial pepperweed (Lepidium latifolium), and medusahead (Taeniatherum caput-medusue), weeds commonly found along the California Department of Transportation (Caltrans) roadsides, is between $10 \%$ and $24 \%$ per year in the United Stares (Duncan et al. 2004).

\section{Reevaluating Roadside Management}

An established stand of native perennial grasses along roadsides has been shown to be effective in controlling non-native weeds, increasing native habitat services, and reducing erosion (Bugg et al. 1997). Native perennial grass establishment can reduce long-term maintenance coits along roadsides because the need for herbicide, mowing, and other weed control measures is reduced (Lulow et al. 2007. Enloe et al. 2005. Brown and Bugg 2001). After native perennial grasses are established, weed corridors are disrupred (von der Lippe and Kowarik 2007) and weed populations are often decreased (Blumenthal et al. 2005. Rose et al. 2001). Additionally, soil sediment transport declines as native perennial grasses increase, either because of their thatch or mulch formation or because of their deeper root development in the soil, when compared to non-native annual grasies (Dyer and Rice 1999, Williamson et al. 2004, Brown and Rice 2000, Bugg et al. 1997, Kemper et al. 1992). Native plants can also provide an alternative and more desirable view for the informed motorist (Olson 1995).

Large planrs and the accumulation of tharch in an established native perennial grass stand often occur in a patchwork manner according to 
plant density, with low density stands producing less plant biomass. In contrast, a small population of yellow starthistle plants with heights greater than $1 \mathrm{~m}$ can cover an area and restrict light from penetrating the soil surface (Young, pers. obs.). Interestingly, Reever Morghan and Rice (2005) report a negative correlation of yellow starthistle populations with increasing size, but not density, of purple needlegrass (Nassella pulchra).

Caltrans and other state departments of transporration (DOTs) have conducted roadside revegetation research (Young and Claassen 2004), but the number of studies on maintenance of sustainable roadside vegetation communities (i.e., native perennial grasses) is limited, with little implementation of the results of these studies (e.g., Brown and Rice 2001). The goal of this study was to document how the impacts of management intensity affect native perennial grass stands populated with the invasive annual yellow starthistle. Our objecrives were to 1) determine the effect of low-intensity management (spray, mow, or burn) and high-intensity management (combinations of those three techniques) on the cover of yellow starthistle and native perennial grasses; and 2) measure the density and activity (i.e., dormancy and growth) of native perennial grasses late in the summer following the control of yellow starthistle. We hypothesized that if a combination of management methods were used to control yellow starthistle along roadsides, then an increase in the existing stand of native perennial grasses would be greater than from any individual treatment. This study contributes to the need for documentation of ongoing efforts to establish native perennial grass stands in California (Stromberg et al. 2007).

\section{Methods}

The study site was located in Colusa County along State Route 20 mile post 8.9 in the low hills of the interior Coast Range of Northern California.
The site was revegetated in 2000 with native perennial grasses following a highway widening project conducted by Caltrans, which began in 1998 . The native perennial grass stand, previously dominated by purple needlegrass and blue wildrye (Elymus glaucus), was densely populated by yellow starthistle by 2003 , prior to the start of this field study. Unlike native perennial bunchgrasses, yellow starthistle has ruderal characteristics including high seed production (Roché et al. 1994), reduced seed dormancy, and rapid root development (Sheley er al. 1993, Benefield et al. 2001). Although yellow starthistle is an annual forb, its morphology and phenology are different from most annual grass and broadleaf species found in California grasslands in that it is active and relatively free from competition during summer.

The regional dimate of the study area is Mediterranean, with a 30 -year mean annual rainfall of $488 \mathrm{~mm}$, most of which falls between October and April (Western Regional Climare Center, Brooks, CA; www.wrcc.dri. edu). Annual precipitation for each rainfall year (as measured from February 1 through January 31) was $421 \mathrm{~mm}$ in $2003 / 2004,850 \mathrm{~mm}$ in $2004 / 2005$, and $427 \mathrm{~mm}$ in 2006/2007. Rainfall during 2003/2004 and 2006/2007 was considered average, but during 2005/2006 was well above average, partially due to heavy precipitation in January of 2006 , which totaled 380 $\mathrm{mm}$.

\section{Experimental Design}

Our experimental design was a randomized complete block design with eight treatments and three replications. Treatments consisted of control (no management), low intensity (burn, mow, or spray) and high intensity (burn + mow, mow + spray, spray + burn, or burn + mow + spray). Plots were established on February 27 along a long, flat stretch of roadside immediately adjacent to the highway. The common ropographical roadside features (e.g., ditches, swales, back slopes), as described by Bugg et al. (1997), were absent from our road location. Each plot was $7.3 \mathrm{~m} \times 9.1$ $\mathrm{m}$ with the shorter side adjacent to the highway.

\section{Timeline of Treatments: 2004}

The entire site was mowed to a height of approximately $20 \mathrm{~cm}$ on March 8 to reduce standing dead plant material from previous years and to improve spray efficacy. The tall mow height assured no deleterious injury to yellow starthistle or the native perennial grasses. On April 23, the broadleaf selective herbicide clopyralid (Transline) was applied to assigned plots at $0.20 \mathrm{~kg}$ a.e. per hectare in a $0.1 \%$ solurion, which was further diluted 1:100 in warer. Spray applications were made on a spray-to-wet basis using a handpressurized backpack sprayer.

The first mow treatment for both low- and high-intensity managed plots was on May 19 at a height of 15 to 20 $\mathrm{cm}$, when most of the yellow starthistle had reached the early flowering stage (less than 5\% of the population flowering). A second mowing was conducted in the mow and mow + burn plots on June 16 at a height of 15 to $20 \mathrm{~cm}$. On July 27 , the mow and mow + burn plots were mowed a third time to control yellow starthistle before full flowering. The burn treatment on August 25 was carried out by California Department of Fire Protection (CDF).

The native perennial grasses had begun to "green up" (produce green shoors) in the burn, mow + burn, spray + burn, and spray + mow + burn on September 29, prior to the onser of the fall rainy season. A few yellow starthistle plants were flowering in the mow treatments and were mowed off before full flowering. No further treatments were applied in 2004.

\section{Timeline of Treatments: 2005}

In addition to yellow starthistle, orher native and non-native annual forbs, hereafter referred to as "annuals," were present on March 9 in both treated and untreated plots including lupine 
(Lupinus spp.), fiddleneck (Amsinckia intermedia), clover (Trifolium spp.), and redstem filaree (Erodium (icutarium).

Clopyralid herbicide at $0.13 \mathrm{~kg}$ a.e. per hectare was applied, similar to 2004 , to the spray, spray + mow, spray + burn, and spray + mow + burn treatments on April 22. The first mow treatment was on June 15 . when yellow starthistle was 25 to 60 $\mathrm{cm}$ tall and less than 5 percent of the population was in the flowering stage. At this time, native perennial grasses were green, approximately $76 \mathrm{~cm}$ tall and inflorescences were near or past the seed-dispersal stage.

On June 17, yellow starthistle plants were still mainly green owing to the late and unusually wet spring. The prescribed burn was conducted in the burn, spray + burn, mow + burn, and spray + mow + burn plots on June 27 . The second mow treatment was on July 29 in the less intensively managed plots. In plots that had high-intensity management, few yellow starthistle individuals remained due to the spray or burn, so plants were mowed individually. No further treatments were applied in 2005.

\section{Timeline of Treatments: 2006}

Annuals, which now included the non-native grasses wild oat (Avenu fatua), ripgut brome (Bromus rigidus), and annual ryegrass were present on March 9. Clopyralid was omitted in 2006 because few yellow starthistle plants were present in the spray plots (see Enloe et al. 2005). The first and only mow treatment in the mow, spray + mow, mow + burn, and spray + mow + burn plots was on June 27. while yellow starthistle was in the early flowering stage. No further treatments were applied in 2006.

\section{Data Collection and Analysis}

On April 11, 2005, cover of yellow starthistle, native perennial grasses, annuals, and thatch was assessed based on the scale of 0 (not present) to 100 (complete cover) (Elzinga er al. 1998). Sampling was conducted along two permanent tra usects that bisected the upper (closer to the highway) and lower (farther from the highway) halves of each plot. Within the first plor, an upper location and rwo lower locations were selerted along each transect. At each location, measurements were taken using a $1-\mathrm{m}^{2}$ quadrat. Along the two transects in the adjacent plot, the quadrat locations were reversed with two upper locations and one lower location. The alternation of three sampling locations was repeated wirhin each plot throughout the entire ex periment to neutralize positional bias within each plot. Quadrat placement along transects was equidistant from both plot edges and between adjacent sampling locations. Following seasonlong treatments and the senescence of annuals, individual native perennial grasses (bunches) and yellow starthistle plants were counted on Octoher 13 in each plor.

In 2006, plant cover was measured on April 18 and individual native perennial grasses and yellow itarthistle plants were counted on October 2 . We collected plant density and cover data to assess population demographics (recruitment and survival), ind cover to evaluate population diversity and dominance, as well as soil cover and protection.

Data were analyzed statistically using analysis of variance (ANOVA). Differences in cover and der sity data were analyzed berween years and individual or high-and low-inten :ity trearments, but not across plant groups (e.g., yellow starthistle, natice perennial grasses, annuals) or thatch. For significant effects, differences between years, rreatments, and intensities were tested using the least significa ut difference method. All statistical analyses were conducted with SAS Version 9.1.3. SAS Institute, Inc.).

\section{Results}

Preliminary field surveys in late winter 2005 indicated native perennial grasses were heavily populated by yellow starthistle (up to 254 plants/ $\mathrm{m}^{2}$, data not shown). From spring 2005 to 2006 , cover of yellow starthistle decreased to I\% or less in the spray, mow + burn, spray + burn, spray + mow, and spray + mow + burn and was not more than $8 \%$ for all remaining treatments, except for the control (Figures I and 2). In 2006, cover of annuals in spray + mow + burn, mow, and mow + burn treatments increased by $4 \%, 10 \%$, and $23 \%$, respectively (Figures 1 and 2). After two years of trearment, purple needlegrass and bluc wildrye cover increased at least $10 \%$ to $15 \%$ in the burn, mow, spray + burn. and spray + mow treatments during the spring (Figures 1 and 2).

Between spring 2005 and 2006, neirher high- nor low-intensity treatments significantly reduced the cover of annuals (Table 1), but high-intensity trcatments significantly increased native perennial grasses from $6 \%$ to greater than $13 \%$ cover while signiftcantly reducing yellow starthistle to less than 1\% (Table 1). In addition, a comparison of high and low intensities revealed yellow starthistle cover to be significantly less for high-intensity treatments (Table 2).

Following the senescence of annuals in early summer 2006, early fall plant counts of yellow starthistle were almost 3 plants $/ \mathrm{m}^{2}$ in the burn treatments and control, which were the highest berween all rrcatments and years (Figure 3). In early fall 2006, plant counts of native perennial grasses were highest in the spray + mow and spray + mow + burn treatments at almost 2 plants $/ \mathrm{m}^{2}$ (Figure 3).

Dormancy of native perennial grasses occurred in late spring to early summer, typical in northern California, and was characterized by browning of leaves and shoots. Native perennial grasses broke dormancy earliest in the high-intensity treatments, prior to the fall rains in both years. From early fall season 2005 to 2006, the number of acrively growing purple needlegrass and blue wildrye plants decreased in the spray + mow, spray + burn, and spray + mow + burn treatments, while 


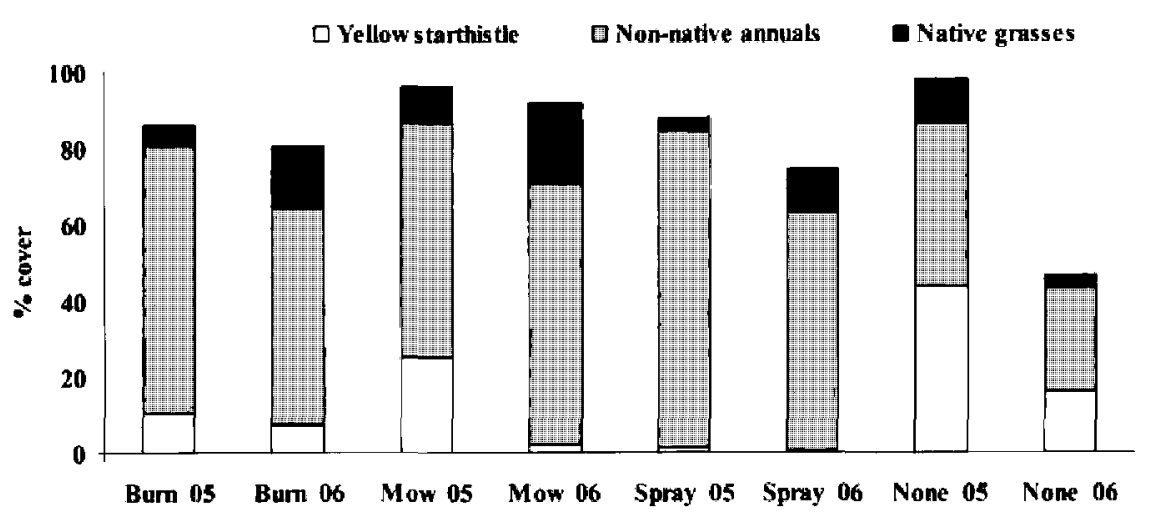

Figure 1. Spring cover of yellow starthistle (Centourea solstitialis) and non-native annuals in a roadside stand of native perennial grasses in Colusa County, California. A single (low-intensity) weed control treatment was applied in 2005 and 2006 . An untreated control (none) was established for comparison.

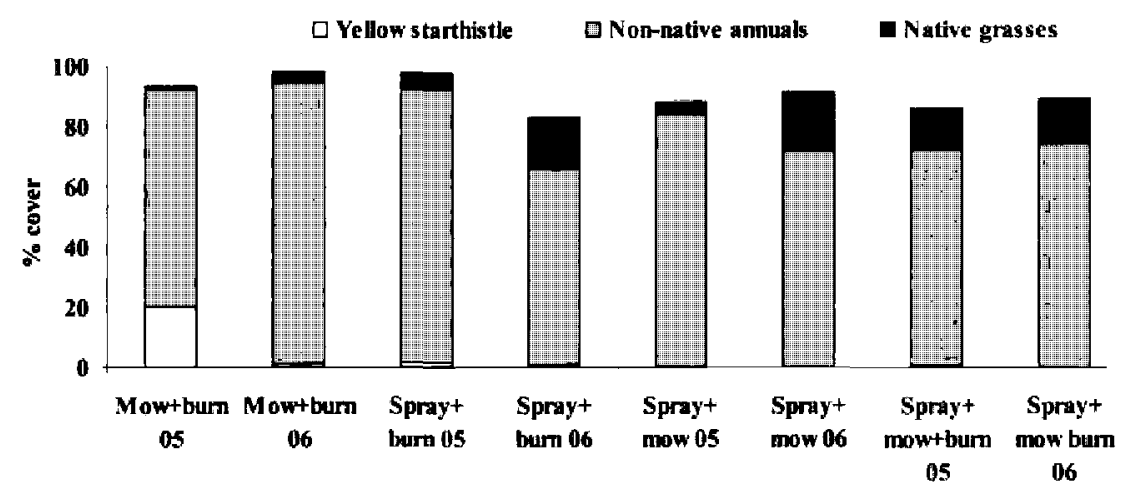

Figure 2. Spring cover of yellow starthistle (Centaurea solstitialis) and non-native annuals in a roadside stand of native perennial grasses in Colusa County, California. Multiple (high-intensity) weed control treatments were applied in 2005 and 2006.

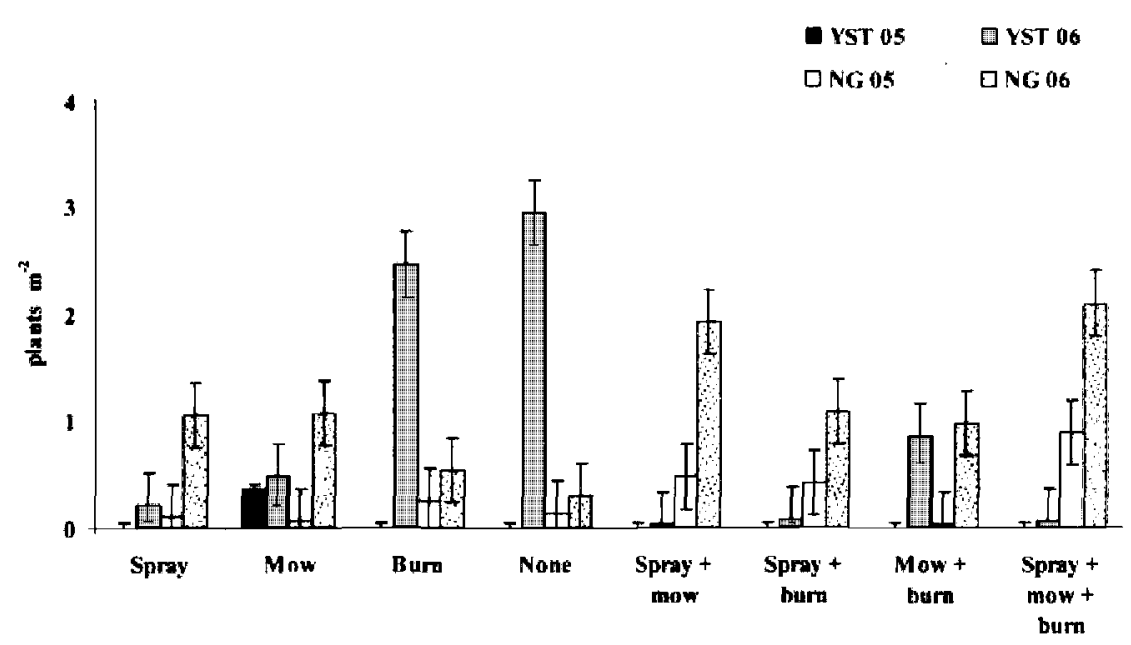

Figure 3. Late summer plant density ( \pm SE) of yellow starthistle (Centoureo solstitiolis) (Y\$T 05 and YST 06) and native perennial grasses (NC 05 and NG 06) during October 2005 and 2006. Weed control regimes include a single (low-intensity) and multiple (high-intensity) treatment(s). An untreated control (none) was established for comparison. the number of dormant native perennial grasses doubled (Figure 4). The fewest actively growing native perennial grasses in the early fall season of 2006 occurred in the control (Figure 4). During this time of year, density of dormant native perennial grasses was always greater than actively growing plants, regardless of treatment.

\section{Discussion}

High-intensity treatments that included spraying clopyralid and that were applied over two years effectively reduced yellow starthistle and increased native perennial grasses, similar to what was found by Enloe et al. (2005). Furthermore, high-intensity treatments may have helped reduce thatch from yellow starthistle, allowing native perennials to spread propagules and have a greater chance for germination and growth. The accumulation of thatch in the low-intensity treatments may have been due to the incomplete control of yellow starthistle. The thatch of yellow starthistle tends to accumulate where management is lacking and can severely restrict the performance of native perennial grasses. Theoretically, native perennial grasses like blue wildrye could directly replace yellow starthistle under appropriate treatment integration and intensity owing to similar resource use patterns between the two species (Young et al. forthcoming).

Although the use of a single vegetation control method (e.g., burn, spray, or mow) is more economical for roadsides, there are drawbacks to repeared use of any one method within the season or over several seasons. For example, although burning reduces plant biomass and stimulates perennial plant growth, open niches can be created for the establishment of non-native, annual plants (Brooks 2006). In addition, a single season of herbaceous plant growth in this region is often inadequate to carry a fire when burning is attempted in several successive seasons (DiTomaso et al. 2006a). Treatments involving only spraying with herbicide eliminate some or all 
Table 1. Mean percent cover of plants and thatch in high and low intensity treatments for spring 2005 and 2006 along a roadside in Colusa County, California. High intensity is a combination of mow, burn, or spray treatments and low intensity is a single mow, burn, or spray treatment. Within a column, percent cover values with the same letter are not significantly different for each intensity level (high or low) according to the least significant difference (LSD) statistical $t$ test at $p<0.05$.

\begin{tabular}{|c|c|c|c|c|}
\hline \multirow[t]{2}{*}{ Comparison } & $\begin{array}{l}\text { Non-native and } \\
\text { native annuals }\end{array}$ & $\begin{array}{l}\text { Native perennial } \\
\text { grasses }\end{array}$ & $\begin{array}{l}\text { Centourea } \\
\text { solstitialis }\end{array}$ & Thatch \\
\hline & \multicolumn{4}{|c|}{$\%$ cover } \\
\hline \multicolumn{5}{|l|}{ High intensity } \\
\hline 2005 & 79.5 a & $5.9 \mathrm{~b}$ & $5.5 \mathrm{a}$ & $9.0 \mathrm{a}$ \\
\hline 2006 & $76.0 \mathrm{a}$ & $13.5 \mathrm{a}$ & $0.4 b$ & $9.8 a$ \\
\hline \multicolumn{5}{|l|}{ Low intensity } \\
\hline 2005 & $64.5 \mathrm{a}$ & $7.2 \mathrm{a}$ & $20.0 \mathrm{a}$ & $8.0 \mathrm{~b}$ \\
\hline 2006 & $53.9 \mathrm{a}$ & $12.7 \mathrm{a}$ & $6.6 \mathrm{~b}$ & $26.5 \mathrm{a}$ \\
\hline \multicolumn{5}{|l|}{ Intensity } \\
\hline Low & $69.2 \mathrm{~b}$ & $10.0 \mathrm{a}$ & $13.4 \mathrm{a}$ & $17.3 \mathrm{a}$ \\
\hline High & $77.8 \mathrm{a}$ & $9.7 \mathrm{a}$ & $3.0 \mathrm{~b}$ & $9.4 \mathrm{a}$ \\
\hline
\end{tabular}

Table 2. Percent plant cover in high and low intensity treatments for spring 2005 and 2006 along a roadside in Colusa County, California. Within a column, plant cover with the same letter was not significantly diffe rent according to the least significant difference (LSD) statistical t test at $p<0.05$.

\begin{tabular}{ccccc}
\hline \multirow{2}{*}{ Treatment } & $\begin{array}{c}\text { Non-native and } \\
\text { native annuals }\end{array}$ & $\begin{array}{c}\text { Native perennial } \\
\text { grasses }\end{array}$ & $\begin{array}{c}\text { Centourea } \\
\text { solstitialis }\end{array}$ & Thatch \\
\cline { 2 - 4 } & \multicolumn{5}{c}{$\%$ cover } \\
\hline High Intensity & & & & \\
Mow + Burn & $82.8 \mathrm{a}$ & $2.1 \mathrm{~b}$ & $10.5 \mathrm{a}$ & $4.6 \mathrm{a}$ \\
Spray + Burn & $77.8 \mathrm{a}$ & $11.0 \mathrm{a}$ & $1.1 \mathrm{~b}$ & $9.8 \mathrm{a}$ \\
Spray + Mow & $77.8 \mathrm{a}$ & $11.5 \mathrm{a}$ & $0.0 \mathrm{~b}$ & $10.6 \mathrm{a}$ \\
Spray + Mow + Burn & $72.8 \mathrm{a}$ & $14.1 \mathrm{a}$ & $0.3 \mathrm{~b}$ & $12.6 \mathrm{a}$ \\
Low Intensity & & & & \\
Burn & $63.6 \mathrm{a}$ & $10.5 \mathrm{a}$ & $9.0 \mathrm{~b}$ & $16.6 \mathrm{ab}$ \\
Mow & $65.3 \mathrm{a}$ & $14.8 \mathrm{a}$ & $13.6 \mathrm{~b}$ & $6.0 \mathrm{~b}$ \\
Spray & $73.0 \mathrm{a}$ & $7.3 \mathrm{a}$ & $0.8 \mathrm{~b}$ & $19.0 \mathrm{ab}$ \\
None & $34.8 \mathrm{~b}$ & $7.3 \mathrm{a}$ & $30.0 \mathrm{a}$ & $27.6 \mathrm{a}$ \\
\hline
\end{tabular}

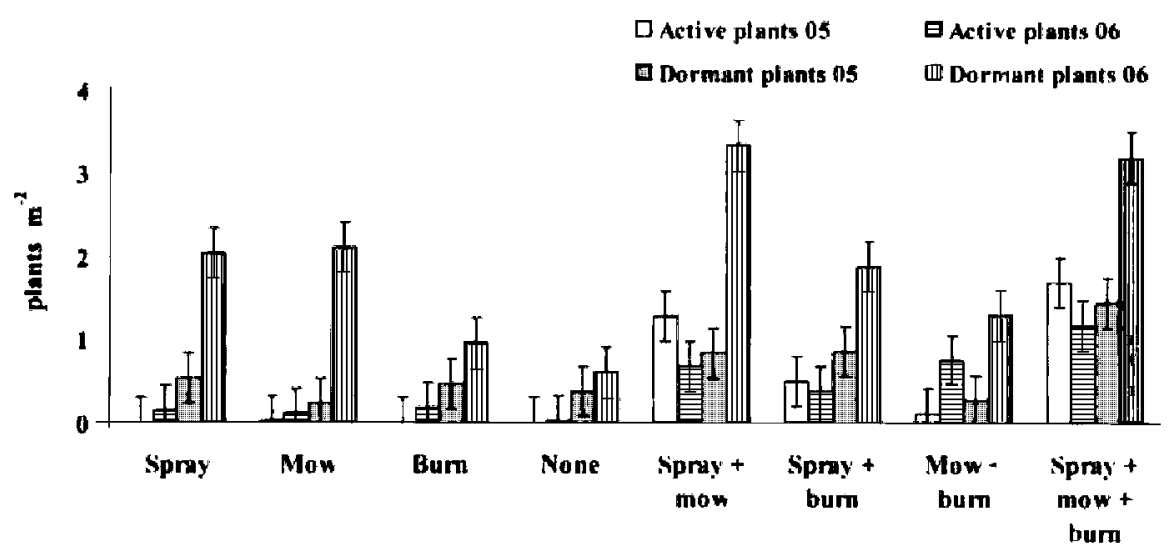

Figure 4. Late summer plant density ( $\pm \mathrm{SE}$ ) of green (active) and brown (dormant) rlative perennial grasses. Measurements were taken during October 2005 (e.g., Active plants 05) and 2006. Weed control regimes include a single (low-intensity) and multiple (high-intensity) treatment(s). An untreated control (none) was established for comparison. plants, depending on selectiveness of the chemical(s), but successive scasonal use increases the porential for development of resistance (Valverde 2007. Heap 1997). Repeated mowing reduces standing plant material but creates large amounts of residue and selects for low-growing plant species (Benefield et al. 1999). The tendency to mow at extremely low heights to reduce the number of trips in a season can fatally harm any native perennial grasses that may exist within the treated area (see Williams et al. 2007). This extremely low-mowed condition, common along roadways, is similar to the overgrazing that has helped eliminate many of the native perennial bunchgrasses that once were the dominant vegetation type in the Great Plains of North America (Bock and Bock 1995) and of the Great Basin and arid southwest (Bahre 1995, Hess and Holechek 1995).

The higher cover of annuals in the high-intensity treatments was duc to an increase in discurbance from the greater number of treatments. Only in low-intensity treatments could the reduction of yellow starthistle be attributed to greater plant cover of annuals (see Young 2007). Most likely, the annuals germinated in the spring once yellow starthistle and thatch had been removed the previous year. The burn treatments stimulated germination of the annuals in addition to native perennial grasses. Under the control treatment, annuals (and native perennial grasses) remained suppressed by yellow starthistle, which is similar to the results of Kepharr (2001).

During the process of reestablishing a native perennial grass stand along a roadside with large populations of yellow starthistle, the newcomer is temporarily replaced by shallow-rooted annuals that are often less destructive in their effects on available deep soil moisture (Enloe et al. 2004, Gerlach 20104; see Gordon and Rice 2000). Invaded native perennial grass stands along roadsides have a better chance of recovery and reestablishment if just yellow starthistle is eliminated and 
large increases of non-native annuals do not occur, not including native annual forbs. The temporal and spatial availability of belowground resources late in the summer favors deep-rooted native perennial grasses such as purple needlegrass and blue wildrye over shallow-rooted, non-native annuals (Reever Morghan and Rice 2006, Dyer and Rice 1999. Holmes and Rice 1996). In this roadside study, we found native perennial grasses responded to a greater degree than annuals when yellow starthistle was reduced to low levels. In successive years, recruitment of additional individual native perennial grass plants from seed production may further increase native plant density (Lenz and Facelli 2005, Hamilton et al. 1999). Furthermore, the biotic resistance of a native perennial grass stand is more effective for invasion resistance than simply limiting the number of yellow starthistle propagules (Gelbard and Harrison 2005, Young et al. forthcoming).

Late summer vigor was observed in $30 \%$ to $50 \%$ of total native perennial grass biomass in the high-intensity treatments. A potential beneficial feature of native perennial grasses that could help to lessen the impacts of fires, particularly along roadsides, is that native perennial grasses may remain green throughout the summer season, depending on deep soil moisture availability. Along some roadways in California and other arid regions, soil moisture from the rainy season is increased by runoff from the roadway, increasing moisture availability for plants near the pavement edge. Additionally, native perennial grasses break dormancy and green up during late summer when conditions are conducive to grass fires. Native perennial grasses could thus help agencies reduce wildfire risk, a growing concern among DO'Ts and policymakers in the United States (O'Laughlin 2005).

We suggest that the presence of yellow starthistle in roadside stands of blue wildrye and purple needlegrass reduces available resources late in the summer season (Young 2007). The loss of deep soil warer to yellow starthistle appears to impede the growth and regeneration of established native perennial grasses (Reever Morghan and Rice 2005, Gerlach 2004). In addition to controlling yellow starthistle along roadsides, we found high-intensity management stimulated more active growth of native perennial grasses than low-intensity management. Because native perennial grasses consume late summer soil water resources, disturbance from appropriate roadside management could stimulate the plants to green up late in the summet season prior to fall rains (see Laud 1953).

\section{Conclusion and Management Implications}

The use of multiple treatments in restoring a stand of roadside native perennial grasses heavily populated with yellow starthistle allows for the maximization of different treatment effects. A combination of treatments prevents 1) the creation of open niches in which invasive species can establish; 2) herbicide-resistant or low-growing species; and 3) a buildup of plant residue, resulting in more rapid achievement of weed control and native plant regeneration along roadsides.

During years of above-average precipitation or in poorly established native grass stands, multiple treatments (e.g., spray, burn, mow) are needed between spring and late summer to reduce heavy populations of yellow starthistle. With adequate populations of native perennial grasses, long-term control of yellow starthistle can be achieved using limited weed management. Although Reever Morghan and Rice (2005) show that as the size of purple needlegrass plants increases the number of yellow starthistle plants decreases, they still warn that management is needed whenever yellow starthistle is present, even at low population densities.

Economics often prohibit the use of native perennial grass plantings (DiTomaso et al. 2006b), but once established, a combination of spraying, burning, and mowing or spraying and mowing along roadsides is most effective for season-long reduction of yellow starthistle and improvement of native perennial grass density and late summer vigor. As long as yellow starthistle remains viable in the seed bank, up to three or four years (Joley et al. 1992), management is necessary. Where yellow starthistle is in or around an established stand of native perennial grasses, the possibility always exists that another invasion and recurrence could happen at any rime. In order to minimize or lower this potential, a low or high level of management is needed.

\section{Acknowledgments}

Funding provided by California Department of Transportation, Office of Landscape Architecture, RTA \#65A0137.

\section{References}

Babbitt, B. 1998. Statement by Secretary of the Interior on invasive alien species. Proceedings of the National Weed Symposium, Denver CO, April 8-10. BL.M Weed Pages. www.blm.gow/weeds/ sympos98/addrbabb.htm]

Bahre, C. 1995. Human impacts on the grasslands of southeastern Arizona. Pages 230-264 in M.P. McClaran and T.R. Van Devender (cds), The Deser Grassland. Tucson AZ: University of Arizona Press.

Benefield, C.B., J.M. Dilomaso, G.B. Kyser, S.B. Orloft, K.R. Churches, D.B. Marcum and G.A. Nader. 1999. Success of mowing to concrol yellow starthistle depends on timing and plant's branching form. California Agricultur $53: 17-21$.

Benefield, C.B., J.M. DiTomaso, G.B. Kyser and A. Tschohl. 2001. Reproductive biology of yellow starthistle: Maximizing late scason control. Weed Science 49:83-90.

Blumenthal. D.M, N.R. Jordan and E.... Svenson. 2005. Effects of prairic restoration on weed invasions. Agriculture, Ecosystems of Enviromment 107:221-230.

Bock, J.H. and C.E. Bock. 1995. The challenges of grassland conservation. Pages 199-222 in A. Joem and K.H. Keeler (eds). The Changing Prairie: 
North American Grasslands. New York: Oxford University Press.

Brooks, M.L. 2006. Effects of fire on plant communities. Pages 29-32 in J.M. DiTomaso and D.W. Johnson (eds), The Use of Fine as a Tool for Controlling Invasive Plants. Cal-IPC Publication 2006-01.

Brown, C.S. and R.L. Bugg. 2001. Effects of established perennial grasses on introduction of native forbs in California. Restoration Ecology 9:38-48.

Brown, C.S. and K.J. Rice. 2000. The mark of Zorro: Effects of the exotic annual grass Vulpia myuros on California native perennial grasses. Restoration Ecology $8: 10-17$.

2001. Inpurs and maintenance for revegetation with native herbaceous species. California Department of Transporcation Report No. FHWA CA/TL-2001/06.

Bugg, R.I., C.S. Brown and J.H. Anderson. 1997. Restoring native perennial grasses to rural roadsides in the Sacramento Valley of California: Establishment and evaluation. Restoration Ecology $5: 214-228$.

DiTomaso, J.M., M.L. Brooks, E.B. Allen, R. Minnich, P.M. Rice and G.B. Kyser. 2006a. Control of invasive weeds with prescribed burning. Weed Technology 20:535-548.

DiTomaso, J.M., G.B. Kyser and M. J. Pitcairn. 2006b. Yellow starthistle management guide. Cal-IPC Publication 2006-03.

Duncan, C.A., J.J. Jachetta, M.L. Brown, V.F. Carrithers, J.K. Clark, J.M. DiTomaso, R.G. Lym, K.C. McDaniel, M.J. Renz and P.M. Rice. 2004. Assessing the economic, environmental and societal losses from invasive plants on rangeland and wildlands. Weed Technology 18:1411-1416.

Dyer, A.R. and K.J. Rice. 1999. Effects of competition on resource availability and growth of a California bunchgrass. Ecology 80:2697-2710.

Elzinga, C.L., D.W. Salzer and J.W. Willoughby. 1998. Measuring and monitoring plant populations. U.S. Department of the Interior Technical Reference 1730-1.

Enloe, S.F., J.M. DiTomaso, S.B. Otloff and D.J. Drake. 2004. Soil water dynamics differ among rangeland plant communicies dominated by yellow starthistle (Centaurea solititialis), annual grasses, or perennial grasses. Weed Science 52:929-935.
2005. Petennial grass es ablishment integrated with clopyralid t eatment for yellow starthistle management on annual range. Weed Tecbnology 19:-)4-101.

Gelbard, J.L. and J. Belnap. 2013. Rnads as conduits for exotic plant it vasions in a semiarid landscape. Conserv ztion Biology 17:420-432.

Gelbard, J.L. and S. Harrison, 2003. Roadless habitars as refugrs for native grasslands: Interactions witic soil, aspect and grazing. Ecological Applications 13:404-415.

2005. Invasibility of roadless grasslands: An experimental study of yellow starthistle. Ecologica' Applications 15:1570-1580.

Gerlach, J.D. 2004. The impicts of serial land-use changes and biological invasions on soil water resources ir California, USA. Journal of Arid Environments $57: 365-379$.

Gordon, D:R. and K.j. liice. 2000. Comperitive suppression of Quercus douglasii (Fagaceae) seedling emergence and growth. American journal of Botany 87:986-994.

Hamilton, J.G., C. Holzaplal and B.E. Mahall 1999. Coexistence and interference between a nat ve perennial grass and non-native annulal grasses in California. Oecologia 121:\$18-526.

Hansen. M.J. and A.P. Clevinger. 2005. Influence of disturbance and habitat on the presence of non-native plant species along transport corridors. Biological Conservation 125:249-25!.

Heap, I.M. 1997. The ocsurrence of herbicide-resistant weeds worldwide. Pesticide Science 51:235-213.

Hess, K. and J.L. Holechek. 1995. Policy roots of land degradatior in the arid region of the United Stares: An overview. Pages 123-141 in D.A. Misuat and C.F. Hutchinson (eds), Descitification in Developed Countries. Boston: Kluwer Academic Publishers.

Holmes, T.H. and K.J. Rice. 1 196. Parterns of growth and soil-water stilization in some exotic annuals and native perennial bunchgrasses of Californta. Annals of Botany 78:233-243.

Joley, D.B., D.M. Maddox, [1.M. Supkoff and A. Mayfield. 1992. Jynamics of yellow starthistle (Centauea solstitialis) achenes in field and labc ratory. Weed Srience 40:190-194.

Kemper D., S. Dabney, L. Kramer, D. Dominick and T. Keep. 1',92. Hedging against erosion. Journal of ioil and Water Conservation 47:284-288
Kephart, P. 2001. Resource management demonstration at Russian Ridge Preserve. Grasslands 9:1-8.

Laud, H.M. 1953. The nature of summer dormancy in perennial grasses. Botanical Gizerte 114:284-293.

Lenz, T.J. and J.M. Facelli. 2005. The role of seed limitation and resource availability in the recruitment of native perennial grasses and exotics in a South Australian grassland. Austral Ecology 30: 684-694.

Lulow, M.E., T.P. Young, J.L. Wirka and J.H. Anderson. 2007. Variation in the initial success of seeded native bunchgrasses in the rangeland foothills of Yolo County, California. Ecological Restoration 25:20-28.

O'Laughlin, J. 2005. Policy issues televant to risk assessments, balancing risks, and the National Fire Plan: Needs and opportunities. Forest Ecology o Management 21 1:3-14.

Olson, P.A. 1995. Cultural perceprion and Grear Plains Grasslands. Pages 25-41 in A. Joern and K.H. Keeler (eds). The Changing Prairie: North American Grasslands. New York: Oxford University Press.

Reever Morghan, K.J. and K.J. Rice 2005. Centaurea sulstitialis invasion success is influenced by Nassella pulchra size. Restoration Ecology 13:524-528. .2006. Variation in resource availability changes the impact of invasive thistles on native bunchgrasses. Ecological Applications 16:528-539.

Roché, B.F, Jr., C.T. Raché and R.C. Chapman. 1994. Impacts of grassland habitat on yellow starthistle (Centaurea solstitialis L.) invasion. Northwest Science 68:86-96.

Ruse, K.K. A.L. Hild, T.D. Whitson, D.W. Koch and L.V. Tassell. 2001. Competitive effects of cool-season grasses on re-establishment of three weed species. Weed Technology 15:885-891.

Sheley, R.L., L.L. Larson and D.E. Johnson. 1993. Germination and root dynamics of range weeds and forage species. Weed Technolog, 7:234-237.

Stromberg, M.R., J.D. Corbin and C.M. D'Antonio. 2007. California Grasshnds: Ecology and Management. Berkeley: University of California Press.

Valverde, B.E. 2007. Sratus and management of grass-weed resistance in Latin America. Weed Technology 21:310-323.

von der Lippe, M. and I. Kowarik. 2007. Long-distance dispersal of plants by vehicles as a driver of plant invasions. Conservation Biology 21:986-996. 
Williams, D.W., L.L. Jackson and D.D. Smith. 2007. Effects of frequent mowing on survival and persistence of forbs seeded into a species-poor grassland. Restoration Ecology 15:24-33.

Williamson, J. and S. Harrison. 2002. Biotic and abiotic limits to the spread of exotic revegetation species. Ecological Applications 12:40-51.

Williamson, T.N., R.C. Graham and P.J. Shouse. 2004. Effects of a chaparralto-grass conversion on soil physical and hydrological properries after four decades. Geoderma 123: 99-124.

Young, S.L. 2007. The effects of species diversity and soil water dynamics on the invasion by yellow starthistle (Centaurea solstitialis) into established California Central Valley plant communities. PhD dissertation, University of California, Davis.

Young, S.L., J.N. Barney, G.B. Kyser, T.S. Jones and J.M. DiTomaso. Forchcoming. Functionally similar species confer greater resistance to invasion: Implications for grassland restoration. Restoration Ecology.

Young, S.L. and V.P. Claassen. 2004. Establishing desirable species along roadsides: Successes and failures. California Department of Transportation. Sacramento: Office of Landscape and Design.
Stephen L. Young. Postdoctoral Research Associate, Center for Precision Agricultural Systems, Washington State University.

Prosser, WA 99350, steve_young@wsu.edu

Vic Claassen, Associate Research Soil

Scientist, Department of Land, Air and Water Resources, University of California, Davis, CA 95616 